\title{
Border experiences along the Portugal/Spain border: a contribution from language documentation ${ }^{1}$
}

\author{
Xosé-Afonso Álvarez Pérez
}

\section{Abstract}

The project Frontera hispano-portuguesa: documentación lingüistica y bibliográfica (FRONTESPO) was born in 2015 with the aim of exploring the linguistic situation of the border between Portugal and Spain, since, in spite of its extraordinary appeal, there was no overall description of it, and most studies were outdated. One of the tools created in the framework of this project was a speech corpus, the result of interviews with 287 informants from different age groups carried out in 64 towns on both sides of the border. In addition to linguistic data, the corpus provides information on border culture and experiences; some examples will be offered in this paper.

\section{Keywords}

Language documentation, speech corpus, personal testimonies, SpanishPortuguese border, FRONTESPO.

\section{Introduction}

The objective of this paper is to present the basic pillars of a linguistic documentation project on the border between Spain and Portugal. Moreover, we aim to demonstrate that the interest in this initiative is not of a purely linguistic or sociolinguistic nature, as it provides information on border community culture and compiles numerous personal experiences from the inhabitants of the said communities regarding several aspects related to life on the border: contraband, clandestine immigration, personal and family relationships on both sides of the Raya ("line"), etc.

1 A Ramón y Cajal Fellowship granted by the Ministry of Economy and Competitiveness (RYC-2013-12761) funds this contribution, which was also developed within the framework of the project Frontera hispano-portuguesa: documentacion lingüistica y bibliográfica (FFI2014-52156-R), for which I am lead researcher. 
Section one presents some basic notes on the historical and linguistic configuration of the Spain/Portugal border for those readers who may not be familiar with it, emphasizing the intense relationship between the two sides of the political border, as well as the richness of the linguistic landscape and the variety of sociolinguistic situations that arise along its 1,200 kilometers. Finally, we provide some information on the changes that the border territory has undergone in recent decades, which have stripped it of some unique characteristics due to depopulation and a lack of generational renewal.

Section two offers an overview of the main reasons behind the creation of the Frontera hispano-portuguesa: documentación lingüistica y bibliográfica (Spain-Portugal Border: Linguistic and Bibliographic DocumentationFRONTESPO) project, with the intention of studying the language and culture (in a broad sense) of this exceptional space. Additionally, we provide a quick presentation of the tools of interest for border researchers: the speech corpus (section 2.1) and the multidisciplinary bibliography (section 2.2).

Finally, the third section of the chapter presents the project's potential with regard to knowledge of the tangible and intangible culture of the Spanish/Portuguese border, as well as of the life experiences of its inhabitants and the sudden changes they have experienced. The exhaustive thematic classification of the audiovisual recordings in the corpus is described; this classification allows users to quickly retrieve information on different aspects of the research. Lastly, samples are provided (selected from among many other possibilities, due to space limitations) of informant testimonies on their individual and group life experiences.

\subsection{Formation and cross-border mobility}

The political border between Spain and Portugal is considered to be one of the oldest boundaries in the world. Certainly, such a statement, as with any historical description on this topic, must be approached with caution, since the current concept of national border is quite different from its meaning prior to the $19^{\text {th }}$ century. In that era, states had not yet established effective mechanisms of oversight over their territory, so political borders were usually a diffuse reality that did not significantly impede mobility or transnational relationships (e.g. Galician monasteries that received donations from the kings of both Portugal and Spain, see Barros 2015). Even in more modern times, the mobile nature of the borders cannot be disregarded, as discussed by geographers Trillo-Santamaría/Paül (2014). 
In any case, and regardless of the significance that may be attributed to this political boundary, the fact is that the border between Spain and Portugal has remained practically unaltered since the Treaty of Alcañices (1297); later, the Treaty of Lisbon (1864) drew a precise demarcation between the two countries.

A distinguishing feature of the Spanish/Portuguese border is its peripherality (Valcuende/Kavanagh/Jiménez 2018, p. 38-41). The majority of both Spanish and Portuguese border regions are poorer than the national average. Moreover, because of the stability of the frontier and the low level of conflict in the area, state administrations were largely absent from this territory, which resulted in a precarious communications network and a lack of bureaucratic, educational, and health services that still persists today.

Consequently, the inhabitants of this marginalized territory had to develop survival strategies; many such strategies consisted of transforming the border into an opportunity. Economic constraints could be solved by resorting to cross-border trading (or smuggling), which took advantage of differences in the availability of essential goods (medicines, coffee, sugar, cloth, and the like) on both sides of the border, as well as the fluctuating exchange rate between Spain and Portugal. The lack of some services (doctors, veterinarians, priests, etc.) could also be solved by visiting the neighboring country. If it was not possible to earn a livelihood in one's own country, some families could walk a few kilometers and begin a new life at the other side of the border, sometimes even founding a new town.

Thus, over the centuries, relationships between the neighboring towns on either side of the border have always been intense (Amante 2010: 102), and are usually stronger than contact with towns located further toward the interior of the same country (Beswick 2014, p. 114). As a result, many borderland communities have developed specific feelings of identity and shared identities (Medina 2006), to the extent that some authors (e.g. Uriarte 1994) argue that there is a border culture. Relationships are intense, but also tense, because of the duality of the inhabitants of the borderlands. They are separated by a state boundary, which has clear symbolic and identity values attached to it, but, at the same time, there is a strong feeling of belonging to a supranational community, because of the intense cross-border relationship. Dialogue between border identity and state identity is always fraught (cf. Godinho 2009). Even self-identification may be quite complicated where there is a mismatch between state bureaucracies and experiences of life. Let us take the example of a testimony collected by Uriarte (2005, p. 74 [translation ours]): 
I was born in La Tojera [Spain] and I was baptized here in La Codosera [Spain]. I went to Portugal to study... well, I only studied for three years, no more... I write in Portuguese. My mother was born in a house 8 meters from the boundary marker, on the Portuguese side, opposite La Tojera. I was raised there. My mother was Portuguese... My father, that's another story. Here in Spain he got into trouble after the Civil War because of politics, so he moved to Portugal. I was five years old, and my brother two. So, my father and my mother were admitted into Portugal, but us, as we were Spaniards, we were rejected.

\subsection{Linguistic configuration of the borderland}

The Spanish/Portuguese border is a complex linguistic mosaic with extremely interesting features, which are merely outlined below.

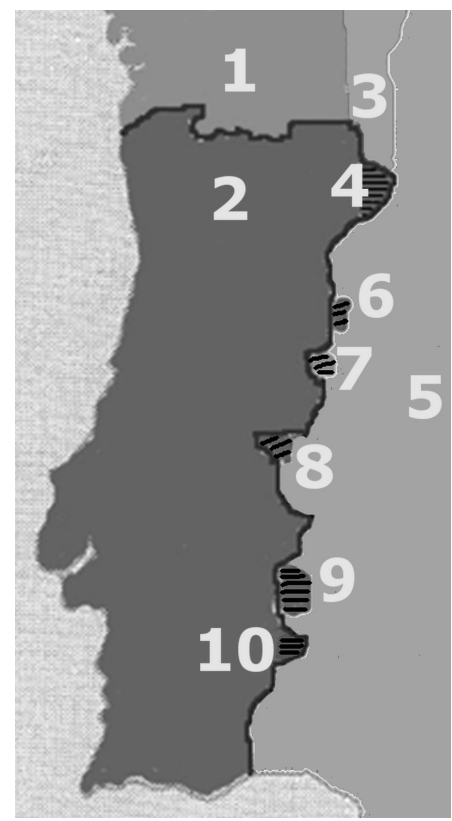

Image 1: Main linguistic areas of the Portugal/Spain border: 1. Galician, 2. Portuguese, 3. Astur-Leonese, 4. Mirandese, 5. Spanish, 6. to 9. Lusophone enclaves along the Spanish side of the border (6. La Alamedilla, 7. Valley of Jálamal Xálima, 8. Herrera, Cedillo and strip of Alcántara, 9. Olivenza), 10. Barranquenho. 
The establishment of a political border separated many territories that were quite homogeneous from a cultural and linguistic point of view. The north of the Iberian peninsula is part of the area known as the Romance continuum. Dialects spoken in that area are a direct evolution of the Latin imported into that territory two thousand years ago; therefore, there are no abrupt linguistic boundaries between adjacent towns or counties, but gradual and soft linguistic variation, with mutual understanding. The independence of Portugal (12 ${ }^{\text {th }}$ century) created a boundary that went through Galician-Portuguese and Astur-Leonese linguistic domains. Thus, the political border gave birth to two branches of the same linguistic system, which have evolved differently ever since, because they were under different state-sponsored languages, they had different centers of social prestige (that is, different models of educated language), and the border usually stopped the expansion of the linguistic innovations that emerged on the other side. This resulted in closely-related languages-Galician and Portuguese, Astur-Leonese, and Mirandese-that, however, have major internal differences (e.g. in terms of grammar and vocabulary) and external differences (e.g. in terms of orthography), as well as different sociolinguistic and legal statuses.

In the central and southern peninsula, linguistic transitions are sharper. Dialects spoken in that extensive area are not a natural evolution, but rather languages imported during the military conquest of the territory in the Middle Ages. Most of this expansion process took place when national frontiers were broadly defined, so linguistic areas more closely follow the limits of the political territories but, even so, there are mismatches.

Along the Spanish side of the border, there are some Portuguese-speaking localities that were the result of a variety of historical situations, such as shifts in the border, migration in different periods of history, and even military conquest (Olivenza). Until the second half of the $20^{\text {th }}$ century, various Portuguese dialects were virtually the only language spoken in these areas, but they have suffered a sharp decline in recent decades, which enhances the appeal of these towns from a sociolinguistic point of view. Because of space constraints, this topic cannot be examined further here, but anyone interested in these territories, known as linguistic enclaves, may find a solid historical and linguistic description of the state of research in Carrasco $(1996,1997,2007)$.

The aforementioned permeability and strong connection between people from both countries over the centuries have increased the appeal and complexity of this linguistic landscape. The inhabitants of both sides of the Raya maintain, as has been said, an intense relationship, and interpersonal contact necessarily entails contact between languages. In day-to-day inter- 
personal communication with their neighbors, dialect varieties are used, which can be quite different from the official language. Because of this contact situation, several processes of convergence and divergence have developed. In some cases, there is accommodation (a speaker adapts their language so their interlocutor can understand it better), as in the case of socalled portuñol, a mixture of Spanish and Portuguese, with interferences from the native language, which allows speakers who are not proficient in the other language to communicate with one another (Marcos-Marín 2001; Lipski 2006).

Nevertheless, the consequences of this language contact are not limited to code-switching situations. The continued cross-border relationship over the years and the relative isolation from the rest of the country have sometimes resulted in the emergence of specific linguistic varieties, such as barranquenho, a mixed Portuguese-based variety strongly influenced by southern Spanish dialects, spoken in the Portuguese town of Barrancos, which has close ties to the Andalusian towns of Encinasola and Rosal de la Frontera (Navas Sánchez-Élez 2011).

\subsection{A changing territory}

The intangible heritage of the borderland is currently undergoing an intense transformation. As happens in many rural areas, its characteristic features have been lost in recent decades, as towns have been immersed in a process of social and cultural homogenization and convergence with the rest of the territory driven by many factors. The generalization of schooling and the expansion of the mass media, especially TV, have contributed to very strong exposure to standard Spanish and Portuguese. Improvements in road infrastructure have generated a significant increase in internal mobility to county and provincial capitals (for shopping, health care, commuters, and the like). This means closer contact with the language spoken in those centers of prestige, therefore opening the way to linguistic harmonization with regional dialects. This loss of characteristic features constitutes an impoverishment of the national language as a whole. As most communities consist of rural towns that are far from prestige centers, from which innovations spread, the dialect varieties spoken there usually preserve archaic traits or specific lexical items (González Salgado 2017) that have disappeared from the rest of the linguistic domain (see an example of this process of change in section 3.2.1).

Furthermore, the traditional rural world is disappearing. Industrialization has resulted in the loss of traditional jobs and, consequently, the dis- 
appearance of the lexicon used in those crafts, as well as associated ethnographic customs. The accentuated depopulation of many towns has also led to a complete rupture with the normal life cycle of any linguistic community. Since young people emigrate to the cities or abroad, internal diversity is quite low, with only elderly people remaining, and the dialects they speak cannot be passed on to the new generations.

In addition to these issues, which are shared with rural territories, as mentioned above, factors related to the specific nature of the border area have also changed. The entry into force of the Schengen Agreement has greatly promoted mobility between Spain and Portugal; the number of cross-border commuters has risen significantly (Falagán/Carlos/Lorenzo 2013), as has cross-border mobility to make everyday purchases. Obviously, this daily human mobility means increasing exposure to the linguistic models of the other country, which may increase linguistic interference and, certainly, enhance some lines of research, such as sociolinguistics or linguistic landscape (cf. Álvarez Pérez forthcoming).

\subsection{A little-known territory}

Border studies is a dynamic research field that has steadily gained importance in recent times. Many works have indicated the extraordinary academic research interest in the borderlands, both inside and outside of Romance Europe, and some of these contributions have touched on linguistic aspects. In fact, in recent years, several books that include different papers with varied approaches and geographical scopes have been published, such as works by Treffers-Daller/Willemyns (2002), Filppula et al. (2005, especially part 1), and Watt/Llamas (2014).

Nevertheless, the linguistic landscape of the Spanish/Portuguese border has not received sufficient attention, despite it being extraordinarily interesting, and despite the unique nature of some of its characteristics. While research activity in the fields of anthropology, economics, and politics is quite intense-see, for example, the recent anthologies by Cairo/Godinho/ Pereiro (2009), Trillo/Pires (2016), or Cairo et al. (2018) — the same cannot be said for linguistics.

Except for some short overall presentations, such as those by Maia (2001), Andrés (2007), and Gargallo (2011), there is no exhaustive study on the linguistic situation along the Spanish/Portuguese border. Although we have some dialect descriptions of areas near the Spanish/Portugal border, they are usually limited to the territory of each country: examinations from the cross-border perspective are scarce. It is true that there are some laud- 
able exceptions, such as Santos (1967), Maia (1977), or Matias (1984); however, their contents are somewhat outdated, since the fieldwork was conducted between 1959 and 1974. The scarcity of primary data available to the research community, particularly in Portugal, must be emphasized. Neither Spain nor Portugal has an overall linguistic atlas: the Atlas Lingüistico de España y Portugal was abandoned, and the Atlas Lingüístico de la Peninsula Ibérica and the Atlas Linguistico-Etnográfico de Portugal e da Galiza are still being edited today, many decades after the fieldwork was completed. In any case, as these are traditional geolinguistic works, they provide a limited typology of data: older speakers, little spontaneous speech, no publication of the recordings, and so on.

In summary, there are no comprehensive studies of the border or a significant portion thereof; in fact, the current linguistic and sociolinguistic situation of some areas and their evolution throughout history remain virtually unknown. In addition, as the main linguistic collections date back more than four decades, and most of them are unpublished or are still being edited, scholars have limited access to the primary data.

\section{A new initiative to research on the borderland: objectives and methods of the FRONTESPO project}

The FRONTESPO project began in 2015 as a sort of reaction to the state of research described under the preceding headings. Its main objective is to achieve an overarching, comprehensive study of the linguistic situation along the entire Spanish/Portuguese border, at present and historically. Accordingly, its main goals are:

a) Preservation (and promotion) of the traditional language spoken along the borderland. As explained in section 1.3, a rich cultural and linguistic heritage is disappearing at an increasing rate. It is imperative, then, to take urgent measures to document this treasure exhaustively, with scientific rigor and in a way that is open to stakeholders and scholars. We do not, however, want to restrict the perspective of the project to a "museumlike" approach. The documentation process must be the first step to show the value of cultural and linguistic diversity, with the ultimate aim of enhancing revitalization.

b) Study of the internal diversity of linguistic communities. Traditional dialectology has prioritized the language of older speakers, since it transmits a "purer" linguistic image. Without renouncing the documentation of traditional language, our project is particularly interested in younger speakers, as they exhibit extremely interesting linguistic and sociolinguistic 
features, because they are more exposed to standard languages via schooling and the mass media, and to regional centers of prestige, as they have greater mobility. An approach to the vision of young people is also necessary because positive attitudes of middle-aged and young speakers are essential for the survival of minority languages in bilingual areas such as Miranda do Douro, Portuguese enclaves in Spain, or the Valley of Jálama among others.

c) Exploration of sociolinguistic issues, with special attention to analysis of the linguistic identities and attitudes within border communities. The Spanish/Portuguese border is an extraordinary laboratory in which to research linguistic identities, attitudes, and even self-assessments of speakers' own dialects. Santos (1967, p. 390) gives an eloquent testimony, an ironic song collected from a Galician peasant from Entrimo (province in Ourense, Spain), where he reflects on his own dialect variety: "Eu non falo castellano | galego nin portugués: | falo entremesellano | que participa dos trés" "I don't speak Castilian | or Galician or Portuguese: | I speak entremesellano $\mid$ which takes things from those three").

However, it is not possible to study the linguistic configuration of the territory without also examining geographic and historical factors that have been key in the said configuration.

a) The first aspect that interests us is cross-border mobility. Cross-border mobility has been a constant throughout different historical periods, both openly (via migrant workers, daily purchases, intermarriage, and the like) and in clandestine contexts such as smuggling, clandestine migration, exile, and political refugees, etc. Interpersonal contact logically brings with it sporadic contact between different national and regional languages, with the consequent phenomena of interference or accommodation. However, sometimes the consequences are more structural. All along the border, there are several Portuguese-speaking enclaves in Spain that are the result of Portuguese migrations (shepherds, agricultural workers, smugglers, etc.) throughout history: Cedillo, Herrera de Alcántara, La Codosera, etc. Our aim, therefore, is to safeguard the speakers' own voices and direct experiences of cross-border mobility and their relationships with the neighboring country.

b) Another crucial aspect that interests us greatly is to highlight shared heritage and experiences. We are deeply interested in the value of unity, in what both sides of the border have in common, and in shared life experiences and memories that overcome the political boundary. In this regard, we embrace the remarks of Beswick (2014, p. 107): "exacerbated no doubt by centuries of military and political disagreement, traditional narratives 
concerning the nature of Spanish and Portuguese identity have generally highlighted differences rather than similarities between the two nations."

c) Finally, in the same way that we have defended the need for linguistic description not to be archaeological, we also believe that research on personal experiences should not be limited to the remote past, but rather the present must also be studied. We are also very interested in the changes in the status quo introduced by the Schengen Agreement. As Kavanagh noted:

Talking not long ago with one of my friends [...] of the changes brought about at his village on the Portuguese/Spanish border by the so-called "Europe Without Borders" (or at least without internal borders), he thought for a moment and then he replied, carefully and repeating his words: "You may remove the door but the doorframe remains... You may remove the door, but the doorframe remains" (Kavanagh 2000, p. 47; cf. also Kavanagh 2011).

FRONTESPO has two tools to fulfill these objectives: a speech corpus and a multidisciplinary bibliography, which will be outlined below. We would also like to mention here our project's commitment to open access, which is essential for data to be available not only to researchers, but also to the communities being studied. It fully embraces the principles of action stated in the Manifeste des Digital Humanities (ThatCamp 2010), and, in order to guarantee free access to the data and the use thereof, the materials gathered or produced by FRONTESPO are available under a Creative Commons Attribution-ShareAlike 4.0. license.

\subsection{Speech corpus of the Portugal/Spain border (FRONTESPO-COR)}

FRONTESPO-COR (http://www.frontespo.org/en/corpus, ISSN 2605-0471) is the result of field research mostly undertaken between July 2015 and June 2016 in nine survey areas along the Spanish/Portuguese border. Sixty-four survey points make up the network. The primary criteria for the choice of the villages to be explored was that all Spanish provinces and Portuguese districts must be present and that a wide variety of linguistic and sociolinguistic situations had to be represented. Additionally, for each of the survey zones, at least one of the locations chosen in each country should have been previously explored in dialect atlases or monographs, so diachronic comparisons could be established.

Two hundred and seventeen individual and group interviews were conducted, with 287 main and secondary informants. At least three informants were interviewed at each survey point, with both sexes represented 
and age stratification in three ranges. As previously explained, we have not followed the archeological perspective of traditional dialectology; we do not neglect the transformations that are being driven by younger generations. However, we also took into account that most of the border towns are small and have an aging population, so it was not advisable to use age ranges of equal length: a) speakers over 75 years old; b) speakers between 50 and 75 years old; c) speakers under 50 years old.

The corpus consists of 290 hours of raw recordings, most of them (237 hours) on video. The fact that most of the interviews were videotaped is a strong asset in terms of both documentation and dissemination. Video recordings capture what is called the multimodality of language: linguistic and semantic information is not transmitted only through the voice, but also with facial gestures, eye and body movement, etc. Additionally, seeing an informant's gestures allows for a better understanding of the explanation of some concepts or activities: the shape of an object, agricultural procedures, a recipe, etc. For non-scholars, an audiovisual corpus is a friendlier format to consult and to share on social networks.

The main thematic core consists of a semi-structured conversation about several semantic fields related to the daily life of borderland communities: agricultural work, cattle, parts of the house, wildlife, winemaking, etc. There is a small questionnaire, with about a hundred concepts, which is a common basis for all the surveys, so it will be possible to establish systematic comparisons throughout the network (e.g. dialectometry or maps to explore lexical variation).

A second section explores the informants' linguistic behavior and identities, such as the (perceived) degree of divergence between their own varieties, neighbors' dialects and the standard; informants' perception of the process of linguistic change within the community; their degree of understanding of the language spoken on the other side of the border, etc.

Finally, the third block consists of a more spontaneous conversation about the informants' experiences related to the border (smuggling, migration, relationships between Portuguese people and Spaniards, and the like) and ethnographic topics (contrast between present-day life and the past, traditional procedures for making bread or cheese, etc.). Thus, we have been able to compile a large amount of material here that has a significant linguistic value, as it documents the informants' spontaneous speech and, at the same time, it can be used by researchers from a wide variety of fields. 


\subsection{Multidisciplinary bibliography of the Portugal/Spain border (FRONTESPO-BIB)}

The borderland is a complex environment in which many factors (demographic, economic, historical, linguistic, political, etc.) intersect in such a way that it becomes impossible to examine certain issues without taking information from other academic fields into account. For instance, it is impossible to research the Lusophone communities in Spain without consulting literature on the historical processes of border delimitation or examining a vast number of works on cross-border migration. The need to consult the literature from several academic fields is an important handicap for border studies, since it is very difficult for scholars to keep up to date with the latest developments; in addition, some scholars are not familiar with bibliographical databases or catalogs from other academic fields. Another important issue is the existence of a significant number of little-known sources, such as articles in local journals or monographs published by the municipalities or local cultural associations, which explains their limited circulation and distribution.

FRONTESPO-BIB (http://www.frontespo.org/en/bibliografia, ISSN 2605-0498) is a user-friendly multidisciplinary database that compiles primary and secondary sources that study the border from any of its multiple perspectives (anthropology, economics, geography, literature, etc.) and enable an understanding of the linguistic situation in the region over the centuries. Currently, the site offers 1,500 records of linguistic items; we are currently working on the publication of 5,000 bibliographical sheets from other fields, but which are also relevant to linguistic studies, since we are not in a position to organize an exhaustive bibliography that covers border studies from all perspectives.

In addition to the bibliographic database, we have included several links to websites: official agencies that manage cross-border programs, studies of the area's cultural or natural heritage, pages studying the language of a particular region, geographic and historical descriptions of border towns, etc. (cf. http://www.frontespo.org/es/enlaces).

\section{Contributions to the study of border culture from a linguistic documentation project}

The main objective of our FRONTESPO project was to collect a speech corpus that would reflect the linguistic diversity within borderland communities. It is essential, for this purpose, to collect fluent and almost spon- 
taneous speech. Informants are expected to be more relaxed when talking about topics present in their daily life, so they may be relieved of the discomfort and artificiality of the interview situation; therefore, the language they produce will be more spontaneous, and it will more closely reflect the dialect features of the linguistic variety the informant uses normally.

Besides that, we wanted to collect information that could be of interest in understanding the linguistic situation of the border: cross-border migrations, interpersonal contact and its intensity now and in past decades, language used in daily communication when the Portuguese and the Spaniards come together in the same place.

Thirdly, the surveys aimed to obtain information about traditional life in border communities that is essential to understanding the vocabulary of many semantic fields. As the Worter und Sachen ("words and things") approach has demonstrated, it is not possible to separate the understanding of lexical designations from the knowledge of the artifacts they refer to. Let us illustrate this with a simple example; anyone who only thinks of modern bee hives-plastic or wood structures with sliding frames inside-will hardly understand the reasoning and etymology behind designations such as the Galician cortizo or Spanish cepo, which recall traditional constructions for apiculture, made with cork (the former) or inside a hollow tree, covered with a stone (the latter).

\subsection{Subject classification of the corpus}

To facilitate searching for the materials, the recordings in our corpus are organized by topic into 10 categories, with 43 topics. Below is a list of the topical categories and the most relevant topics within each one, along with descriptors or additional information, as necessary.

\section{Cross-border relationships}

- Trade and smuggling: products, means of concealment, routes, etc.

- Migrations: economic migrants, clandestine border crossings, deserters and people who avoided military service, political refugees, etc.

- Relationships with people from the other side of the border: at fairs, on pilgrimages, in stores, etc.

- Relationships with the state and its agents, especially encounters with customs officers from both sides, although other authorities are not excluded. 
Historical and geographic context of border communities

- Economic and social transformations in recent decades: depopulation, aging, economic migrations, loss of traditional way of life, etc.

- The rediscovery of the Couto Misto, a sort of microstate that was the result of complex medieval feudal relationships. It became extinct with the Treaty of Lisbon (1864). However, in the mid-1990s, the interest in this territory re-emerged both in academic and cultural groups (see, for example, García Mañá 2000), which promoted the recognition of its unique nature and the symbolic restitution of its legal institutions.

- Testimonies on the Spanish Civil War (1936-1939), especially from the Portuguese side of the border, which was a place of refuge, albeit not always successfully (cf. Simões 2016).

Linguistic attitudes and behavior. Identity

- Linguistic situation in the community: differences between the language of older and younger people, linguistic transmission, and prospects for the future.

- Language in the neighboring places in the same country: degree of (perceived) linguistic difference from neighboring towns from Spain and Portugal.

- Language of the neighboring country and linguistic behavior with nationals from the other country: is there mutual comprehension? Must they change or adapt their language? Which country do they associate themselves with? These kinds of assessments are particularly interesting when surveying certain communities: Lusophone towns on the Spanish side of the border, people whose family history comes from the other country, etc.

Agriculture and livestock. Crafts and trades

- Horses and pack animals. Sheep and goat breeding. Pig farming. Cattle.

- Trees and forestry use.

- Gardens and fruit trees. Grains. Volunteer plants.

- Kinds of plots and agricultural operations.

- Processed products: bread, clothing and weaving, dairy products, olive oil, wine, etc.

- Tools and farm implements. 
Other aspects of cultural and material reality

- Romantic relationships and family.

- Meals and parts of the day.

- Parts of the body.

- Parts of the house and related buildings. Furniture and household utensils.

- Stories and legends.

- Other ethnographic information (e.g. folk medicine).

As can be seen, this topical classification in such a large corpus will allow researchers to access extensive information on the border between Spain and Portugal from diverse perspectives, not just in the field of linguistics. This is because the corpus preserves and disseminates information and personal testimony on several subjects, especially those related to the material reality of border cultures, mobility, and interpersonal contact. In the next section, we will provide some samples as an example of the potential of this corpus.

\subsection{Sample of border experiences}

Due to limited space, the texts are offered directly in English (the translation is ours), except in the case of section 3.2.1., as a linguistic issue is commented on, and it is therefore important to respect the statement in the same language in which it was created. In any event, those interested may consult the original texts on the website for our speech corpus: http://www .frontespo.org/en/corpus.

\subsubsection{Intergenerational dialogues with a transforming language}

As has been remarked in section 1.3, the border region is undergoing a significant process of social, economic, and cultural change, of which the transformation of the language is a part. As a tangible example of the process of linguistic change, we have selected a fragment from an interview with Informant 1, born in 1952 in the town of Sela (province of Pontevedra, Spain), but who lives during the working week in the city of Vigo, fifty kilometers from there, and who is thus exposed to another Galician dialect, and, above all, to Spanish. Another inhabitant of Sela, Informant 2, 18 years older, also attended the interview, and he could not resist the 
temptation to correct certain answers provided during the conversation (highlighted in italics).

INTERVIEWER: E... e cando se deixa un terreo... repousar e... non se labra dun ano para, para que despois teña máis forza?

INFORMANT1: O barbecho. Eso era barbecho, non? Si, creo que era, si.

INFORMANT2: E / ou resteba.

INT: Resteva?

INF1: Bueno, si, dito doutra maneira, si. E-, el [INF2] logo vaiche dar información...

INF2: Ermo.

INT: Ermo tamén?

INF1: $\mathrm{Si}$.

INF2: Tamén se lle dicía ermo.

$[\ldots]$

INF1: Esa é a naranxa.

INT: E a árbore?

INF1: O nara- | a naranxeira... naranxeira, laranxeira...

INT: E cada un $\mid$ E cando se quita a casca, cada unha das...?

INF1: Gagos | ja- | ga- | jagos -como é, gajos, ou...?

INF2: Tetos.

INF1: $\mathrm{Si}$.

INF2: Tetos.

INF1: Si, iso depende de... Si, cada, cada [...]

INF1: A | cereixas, a cereixeira.

INT: Cereixeira. | E o que....?

INF2: Cerdeira

INF1: Ou a ce- | ou cerdeira... si, si, si, si.

INF2: Cerdeira, cereixeira.

INT: E o que ten dentro, que é duro?

INF1: Ese [sic] é a pepita.

INF2: Esa é a carabulla.

INF1: A carabuñ- | si, pepita ou carabuña, si.

INT: Carabuña.

INF1: Ch- | Depende...

INT: E... aquí [fotografía]

INF1: As castañas...

INT: E a árbore?

INF1: O castiñeiro.

INF1: Ah... esas son as noces, o nogal. 


\section{INF2: Nogueira. Nogueira}

INF1: A nogueira, si. Máis que nada nogueira.

$[\ldots]$

INT: Moi ben, e... a... a parte de fóra do pan?

INF1: A f- |-do... pan? | A corteza... | a casca, a casca.

INF2: Codia...

INF1: Casca | codia, si.

INT: E o de dentro?

INF1: O de dentro é miga.

INF2: Miolo...

INF1: Bueno, miga... [Riso]

INT: [Riso] Vale, e...

INF1: É, é, é | iso vese | vai en plan de... unha década, máis ou menos, temos unha... unha visión distinta. ${ }^{2}$

INF1's answers are clearly influenced by Spanish (barbecho, naranxeira, nogal, pepita, miga) or other Galician varieties (casca, cereixeira), while INF2 still retains the traditional designation that was used in the town. In fact, when INF2 corrects INF1, the latter acknowledges it, and he usually agrees that the designation provided by INF2 is more genuine. That is, he retains traditional forms in his passive vocabulary, but he has lost them as active

2 To make the situation more understandable, I was compelled to provide some English synonyms that are not normally used. This is not the case in the original forms; their vitality is quite similar in current oral and popular Galician. II INT: And... when you let a field... rest and it is not plowed for a year, so it gains strength? | INF1: Fallow. It was fallow land, wasn't it? Yeah, I think so. INF2: And / or unplowed. / INT: Unplowed? | INF1: Yes, well, said in other words, yes. He [INF2] will tell you later... INF2: Barren. / INT: Also barren? | INF1: Yes. | INF2: It was also called barren. / [...] INF1: This is an orange. INT: And the tree? INF1: Oran| orange tree... orange tree... INT: And each of them | When you remove the peel, each of the...? INF1: Pieces | Pea- | Pie - | Peace - How do you say it, pieces, or...? INF2. Wedges. INF1: Yes. INF2: Wedges. INF1: Yes, it depends on... Yes, each, each... [...] INF1: Cherries, cherry tree. INT. Cherry tree | And the...? INF2: Prunus. INF1: Or pru- $\mid$ or prunus... yes, yes, yes, yes. INF2. Cherry tree, prunus. INT. And what is inside, that's hard? INF1: This is the seed. INF2: This is the stone. INF1: The stone | Yes, seed or stone, yes. INT: Stone. INF1. It depends... INT: And... here [looking at a photo]. INF1: Chestnuts. INT: And the tree? INF1: Ah..., these are the walnuts, the walnut tree. INF2: Juglans. Juglans. INF1: Juglans, yes. Above all, juglans. [...]. INT. Very good. And... and the outside part of a piece of bread? INF1: Of bread... The rind... The peel, the peel. INF2: Crust. INF1: Peel, crust, yes. INT: And the inside part? INF1. Inside, it is a crumb. INF2: Center... INF1: Well, crumb... [he laughs]. INT [Laughs] OK, and... INF1: That shows | About a decade... more or less, we have a... a different perspective. 
lexis. This concrete example is evident proof of the necessity to systematically document all the linguistic varieties spoken in the borderlands. In order to get a realistic picture, it is imperative to gather all kinds of data, and to compare the linguistic features of each age band.

\subsubsection{The border as the limit of state... and clerical authority}

Informant M., from the town of La Alamedilla (Salamanca, Spain), born in 1939, remembers that the town priest was very strict about prohibiting dances and parties during Lent, so the town's young people used to cross the border and dance on the hill, on the other side of the Raya, where the priest was powerless to do anything; his spiritual power was also limited by the confines of worldly power:

He wouldn't let us dance here. We were little couples, already into all of that, and, of course, we wanted to dance, but since it was Lent, he wouldn't let us dance and here, since it was like that, he would follow us, the guy, if we went to dance or sing on that crest over there, he was going to catch us $[. .$.$] so what did we do? [...] we went a few trees past$ the Raya, and we would go there to dance, and he was going to catch us there, the priest, he was going to catch us, but we didn't pay any attention to him, we would say to him, "Hey, man, we're in Portugal, we can dance." Some would hide, others couldn't. But we were a bit cheekier and when he said to us, "Fine, you'll have to come back down to the town eventually," we said to him, "OK, well, when we come down, you'll say something then, but now we're here in Portugal."

\subsubsection{Deserters and draft dodgers during the Portuguese Colonial War}

In the town of Messegães (in the local government area of Monção), we have collected detailed testimony on the heartrending consequences of the Portuguese Colonial War, a long, difficult confrontation between the Armed Forces of Portugal and different national liberation movements in the territories of Angola, Guinea-Bissau, and Mozambique between 1961 and 1974.

To avoid being drafted (or sent to Africa if they were already in the army), it was common for men of military age to try to cross the border illegally, to continue on to France or another country, where they could seek refuge. This was a very dangerous decision, as they not only had to es- 
cape Portuguese authorities, but also the Spanish Civil Guard, which would hand the fugitives over to Salazar's police, with harsh consequences for them:

- And your husband, and your husband was another one who fled... and many, many, many fled. [...] Those times were very difficult for the mothers, poor things, because it's one thing to say it and another to do it. As it happened, I, at the time, didn't have anyone; my brother was already a much older man and he already had another life. But the people who had children of military age at that time suffered a lot, a lot, a lot. And that boy, that C., had his entire family here, his mother, father, sisters, they had three sisters, he had everything; he spent years, I don't know how many, without seeing any of them. But it wasn't, it wasn't because he didn't want to come. He couldn't... if they caught him, they would arrest him. Being arrested at that time for not doing your military service was worse, it was worse, like political [prisoners], they would take them to [the penal colony of] Tarrafal. Life was very, very difficult for young men. But then the $25^{\text {th }}$ of April [revolution] happened, and they came back... we were very happy. I remember that boy, when he arrived here, he visited everything, all of the houses; he seemed crazy.

- And so many, so many that left, even men who were already married and everything [...]

- They called them carneiros ['lambs'].

- They crossed the river here [...] they had certain places where the other smuggler who picked them up was waiting there at that place that they had agreed on, that's what they said, right? I'm not really sure. And then they went by train, but they got to a point that they had to do something, I'm not sure what, get off the train, and hide there in a place, waiting for someone to come get them, only then after the Spanish Civil Guard got them, if they got them, they came back, prison by prison, on their way to Portugal, and they suffered a lot along the way.

\subsubsection{Blended identities along the Spanish bank of the Guadiana River}

In the westernmost part of the province of Huelva, on the Spanish side of the Chanza/Chança and Guadiana Rivers, Portuguese speakers can be found today. They are Spanish citizens descended from miners, shepherds, or agricultural workers who crossed the border in different waves over the centuries; the most recent wave dates back to the 1920s, and the majority 
of the inhabitants who remain in the area are the third generation. Generally, they are bilingual speakers, who use Spanish with strangers or with the inhabitants of the municipal capitals, where many have gone to live (cf. López de Aberasturi 2016).

The informant A. G. A. was born in 1941 in El Romerano (Romerão), in the province of Huelva (Spain). His parents were also born in Spain, but three of his four grandparents were Portuguese, from the Guerreiros do Rio area, on the other side of the Guadiana, less than $1 \mathrm{~km}$ away. When asked by the interviewer about his self-identification in terms of nationality, he responds that he considered himself Portuguese in his town, since that language was spoken there; however, in other Spanish towns, he presented himself as "Spanish". Curiously, when he and other young people from the town made fun of the fishermen who came from Portugal, they referred to them as "Portuguese" (demonym followed by a series of imprecations).

- How did they see themselves, how do you see yourself?

- There I saw myself as Portuguese, because I spoke Portuguese, I considered myself to be Portuguese

- Even though you have a Spanish national identification document?

- Of course, we only ever talked about Portugal, because we saw ourselves as Portuguese; once you leave there, then not anymore, then you say "I'm Spanish". While I was in El Romerano, we only spoke Portuguese... Even to make fun of the fishermen, who were with, with, with their boats, to catch fish.

- With those... what did they call them, the colher ["spoon"]...

- Colher. With a colher. They couldn't come to Spain with the colheres.

- No?

- They couldn't come to Spain, because we were, we were so sick that four or five of us young guys would get together when we saw them coming, we'd take a ton of rocks, like that, we'd hide, and when they had put out their net, boom, boom, boom, boom, we'd drop the rocks, their nets were full of rocks. Of course, the nets were full of rocks so they started to go like this, to get the rocks out, because the nets were breaking. And the man started to yell, "hey, sons of bitches," and on and on, and we said to him, "go on, you Portuguese fat ass"... We were very sick, very sick. 


\section{Conclusion}

In the preceding pages, we have attempted to demonstrate the extraordinary linguistic, cultural, and anthropological appeal of the Spain/Portugal border. Although this border space has been in the midst of a complex process of socioeconomic transformation for decades that has led to the loss of many of the traits that differentiated it from the rest of Spain and Portugal, it is still possible to document a good deal of intangible cultural heritage. Part of this legacy are the numerous personal testimonies of the community's inhabitants, which provide information on different aspects of their lives, both from a personal as well as a collective perspective: the scarcity they experienced in their youth, the emigration which emptied out towns, the new machinery that has transformed agricultural and livestock production, and, of course, numerous experiences related to living on the border, from diverse perspectives.

Therefore, undertaking a systematic process to document the intangible cultural heritage of the border is justified. In this regard, we have explained the foundations of the FRONTESPO project and its main components, and have demonstrated that, although it is a linguistic documentation initiative, it has the potential to provide results of enormous interest to researchers in other fields. The examples given in section 3.2., although scant due to space limitations, bring to light several very interesting issues for border studies, such as the linguistic transformation of communities (Sela), moving from one side of the border to the other to free oneself of the restrictions of one's own country-whether in a festive atmosphere (La Alamedilla), or in a more tragic context, that of the Portuguese Colonial War (Messegães)-, and the blended identities that result from a porous border where the political limits do not match the linguistic boundaries (El Romerano). As the distinguished writer and economist José Luis Sampedro wrote (not in reference specifically to the Spanish/Portuguese border, although this reflection fully applies):

My borders are all transcendable, like the membrane of a cell, without whose permeability, life would not be possible; life, which is giving and receiving, exchange, crossing boundaries. And even more than transcendable, the border is provocative, erecting itself as a challenge, a loving invitation to be crossed, to be possessed, to deliver itself to give us with its defeat our triumph: that is the profound enchantment of living on the border. Enchantment comprised ambivalence, ambiguity (they are not the same), overlapping, living here and there at the same time without erasing the differences. 
Those in the center, on the other hand, experience the border in the opposite manner. That adventure repels them, or unsettles them, and they retreat from the border inwards, like the ebbing sea. They withdraw to the center of the enclosed space; they settle into black and white, fearful of the infinite, delicate grays. (Sampedro 1991, p. 16-17)

\section{References}

Álvarez Pérez, Xosé Afonso (forthcoming): Language contact on the Spanish-Portuguese border: a contribution from the linguistic landscape perspective. In: Bouzouita, M./Enghels, R.: Different perspectives on convergence and divergence in Ibero-Romance: language contact and contrasting national varieties [working title]. Berlin: De Gruyter.

Amante, Maria Fátima (2010): Local discursive strategies for the cultural construction of the border: the case of the Portuguese-Spanish border. In: Journal of Borderlands Studies 25, no. 1, p. 99-114, https://doi.org/10.1080/08865655.2010. 9695754.

Andrés Díaz, Ramón de (2007): Linguistic borders of the Western Peninsula. In: International Journal of the Sociology of Language 184, p. 121-138, https://doi. org/10.1515/IJSL.2007.018.

Barros, Carlos (2015): A fronteira medieval entre Galiza e Portugal. In: Debater a História 2, no. 7, p. 27-40.

Beswick, Jaine (2005): Linguistic homogeneity in Galician and Portuguese borderland communities, In: Estudios de Sociolingǘstica 6, no. 1, p. 39-64.

Beswick, Jaine (2014): Borders within borders: Contexts of Language Use and Local Identity Configuration in Southern Galicia. In: Watt, D./Llamas, C. (eds.): Language, borders and identity, Edinburgh: Edinburgh University Press, p. 105117.

Boller, Fred (1995): Die Isoglossenstaffelung in der galicisch-portugiesisch-spanischen Kontaktzone und im Lombada-Aliste-Grenzgebiet. Kiel: Westensee-Verlag.

Boller, Fred (1997): Contacto lingüístico entre el gallego-portugués y el asturianoleonés en la provincia de Zamora. ¿Frontera nítida o zona de transición? In: Lletres Asturianes 65, p. 7-31.

Cairo, Heriberto (ed.) (2018): Rayanos y forasteros. Fronterización e identidades en el límite hispano-portugués. Pozuelo de Alarcón: Plaza\&Valdés.

Cairo Carou, Heriberto/Godinho, Paula/Pereiro, Xerardo (eds.) (2009): Portugal e Espanha. Entre discursos de centro e práticas de fronteira. Lisboa: Colibri.

Carrasco González, Juan M. (1996): Hablas y dialectos portugueses o galaico-portugueses en Extremadura. (Parte I: Grupos dialectales. Clasificación de las hablas de Jálama). In: Anuario de Estudios Filológicos, vol. XIX, p. 135-148. 
Carrasco González, Juan M. (1997): Hablas y dialectos portugueses o galaico-portugueses en Extremadura (parte II y última: otras hablas fronterizas; conclusiones). In: Anuario de Estudios Filológicos, vol. XX, p. 61-79.

Carrasco González, Juan M. (2007): Falantes de dialectos fronteiriços da Extremadura espanhola no último século. In: Limite: Revista de Estudios Portugueses y de la Lusofonía vol. 1, p. 51-69.

Falagán Mota, Jorge/ Carlos Villamarín, Pablo de/Lorenzo Alonso, Pedro (2013): Movilidad transfronteriza de trabajadores entre Galicia y el norte de Portugal. In: Contabilidad y negocios 8, no. 15, p. 77-94, revistas.pucp.edu.pe/index.php/ contabilidadyNegocios/article/view/6768, 5/14/2018.

Filppula, Markku et al. (eds.) (2005): Dialects across Borders: Selected Papers from the $11^{\text {th }}$ International Conference on Methods in Dialectology. Amsterdam/ Philadelphia: John Benjamins.

García Mañá, Luis Manuel (2000). Couto Mixto. Unha república esquecida. Vigo: Universidade de Vigo.

Gargallo Gil, José Enrique (2011): Fronteras romances en la Península Ibérica. In: Andrés Díaz, R. de (ed.): Lengua, ciencia y fronteras, Uviéu: Trabe, p. 35-68.

González Salgado, José Antonio (2017): El léxico portugués en las hablas dialectales de las comarcas rayanas españolas. In: Corbella, D./Fajardo, A. (eds.): Español y portugués en contacto. Préstamos léxicos e interferencias. Berlin: De Gruyter Mouton, p. 105-127.

Godinho, Paula (2009): Discursos palacianos. In: Cairo Carou, H./Godinho, P./ Pereiro, X. (eds.) (2009): Portugal e Espanha. Entre discursos de centro e práticas de fronteira. Lisboa: Colibri, p. 73-91.

Kavanagh, William (2000): The Past on the Line: The Use of Oral History in the Construction of Present-day Changing Identities on the Portuguese-Spanish Border. In: Ethnologia Europaea 30, no. 2, p. 47-56.

Kavanagh, William (2011): Identidades en la frontera luso-española: permanencias y transformaciones después de Schengen. In: Geopolítica(s) 2, no. 1, p. 23-50, http://dx.doi.org/10.5209/rev_GEOP.2011.v 2.n1.37896.

Lipski, John M. (2006): Too close for comfort? The genesis of "portuñol/portunhol”. In: Face, T. L./Klee, C. A. (eds.): Selected Proceedings of the $8^{\text {th }}$ Hispanic Linguistics Symposium. Somerville, MA: Cascadilla Proceedings Project, p. 122.

López de Aberasturi, José Ignacio (2016): Dinámica sociolingüística y lenguas en contacto en la comunidad de habla de Ayamonte. PhD thesis. Granada: Universidad de Granada, digibug.ugr.es/handle/10481/46830, 9/23/2018.

Maia, Clarinda de Azevedo (1977): Os falares fronteiriços do concelho do Sabugal e da vizinha região de Xalma e Alamedilla. Coimbra: Universidade de Coimbra. 
Maia, Clarinda de Azevedo (2001): Fronteras del español: aspectos históricos y sociolingüísticos del contacto con el portugués en la frontera territorial. In: II Congreso Internacional de la Lengua Española: El español en la sociedad de la información. Valladolid: Instituto Cervantes, Centro Virtual Cervantes. cvc.cervantes.es/obref/congresos/valladolid/ponencias/unidad_diversidad_del_espanol/ 5_espanol_y_portugues/azevedo_c.htm, 5/14/2018.

Marcos-Marín, Francisco (2001): De lenguas y fronteras: el espanglish y el portuñol. In: Nueva Revista de Política, Cultura y Arte, vol. 74, p. 70-79. www.nuevarevista.net/revista-lecturas/de-lenguas-y-fronteras-el-espanglish-y-el-portunol/, $5 / 14 / 2018$.

Matias, Maria de Fátima de Rezende Fernandes (1984): Bilinguismo e níveis sociolinguísticos numa região luso-espanhola (concelhos de Alandroal, Campo Maior, Elvas e Olivença). Coimbra: Instituto de Língua e Literatura Portuguesas, Faculdade de Letras da Universidade de Coimbra.

Medina García, Eusebio (2006): Orígenes históricos y ambigüedad de la frontera hispano-lusa (La Raya). In: Revista de Estudios Extremeños 62, no. 2, p. 713-724.

Navas Sánchez-Élez, María Victoria (2011): El barranqueño: un modelo de lenguas en contacto. Madrid: Universidad Complutense.

Ossenkop, Christina (2013): Spanisch-portugiesischer Sprachkontakt in der Extremadura am Beispiel der Gemeinden Cedillo, Valencia de Alcántara und La Codosera. Wilhelmsfeld: Gottfried Egert Verlag.

Sampedro Sáez, José Luis (1991): Desde la frontera. Discurso leído el día 2 de junio de 1991, en su recepción pública, por el Excmo. Sr. Don José Luis Sampedro Sáez y contestación del Excmo. Sr. Don Gregorio Salvador Caja. Madrid: Real Academia Española. Www.rae.es/sites/default/files/Discurso_Ingreso_Jose_Luis_Sampedro.pdf, 9/28/2018.

Simões, Dulce (2016): A guerra de Espanha na Raia luso-espanhola. Resistências, solidariedades e usos da memória. Lisboa: Colibri.

Santos, María José de Moura (1967): Os falares fronteiriços de Trás-os-Montes. Coimbra: Universidade de Coimbra.

ThatCamp (2010): Manifeste des Digital Humanities. https://tcp.hypotheses.org/31 $8,16 / 04 / 2019$.

Treffers-Daller, Jeanine/Willemyns, Roland (eds.) (2002): Language Contact at the Romance-Germanic Language Border. Clevedon; Buffalo: Multilingual Matters.

Trillo-Santamaría, Juan-Manuel/Paül, Valerià (2014): The Oldest Boundary in Europe? A Critical Approach to the Spanish-Portuguese Border: The 'Raia' Between Galicia and Portugal. In: Geopolitics 19, no. 1, p. 161-181, https://doi.org/10.10 80/14650045.2013.803191.

Trillo Santamaría, Juan Manuel/Pires, Iva (eds.) (2016): Fronteras en la investigación peninsular: temáticas y enfoques contemporáneos. Santiago de Compostela: USC.

Uriarte López, Luis M. (1994): La Codosera: culturas de frontera y fronteras culturales en la raya luso-extremeña. Mérida: Asamblea de Extremadura. 
Uriarte López, Luis M. (2005): Culturas de frontera y fronteras culturales: la raya hispano-lusa y peruano-ecuatoriana. In: Arquivo de Beja, série III, tomo I, p. 7384.

Valcuende, José María/Kavanagh, William/Jiménez, Juan Carlos (2018): Rasgos principales de la frontera hispano-portuguesa. In: Cairo, H. (ed.): Rayanos y forasteros. Fronterización e identidades en el límite hispano-portugués. Pozuelo de Alarcón: Plaza y Valdés, p. 37-49.

Watt, Dominic/Llamas, Carmen (eds.) (2014): Language, Borders and Identity. Edinburgh: Edinburgh University Press.

\section{About the author}

Xosé-Afonso Álvarez Pérez | Universidad de Alcalá | Departamento de Filología, Comunicación y Documentación | 3, Trinidad | 28801 Alcalá de Henares | Spain | xoseafonso.alvarez@gmail.com

Ph.D. in Linguistics (2008), BA in Romance Language Philology (2003) and Galician Philology (2005). Ramón y Cajal researcher at the University of Alcalá (Spain); his main lines of research include dialectology, geolinguistics, Romance linguistics, and minority languages. Further information is available on his personal website: www.geolinguistica.org/cv 